\title{
Kainic acid in the seaweed Palmaria palmata (Dulse)
}

\author{
Jørgensen, Kevin; Olesen, Pelle Thonning
}

Published in:

Food Additives \& Contaminants. Part B. Surveillance

Link to article, DOI:

10.1080/19393210.2018.1462258

Publication date:

2018

Document Version

Peer reviewed version

Link back to DTU Orbit

Citation (APA):

Jørgensen, K., \& Olesen, P. T. (2018). Kainic acid in the seaweed Palmaria palmata (Dulse). Food Additives \& Contaminants. Part B. Surveillance, 11(3), 198-200. https://doi.org/10.1080/19393210.2018.1462258

\section{General rights}

Copyright and moral rights for the publications made accessible in the public portal are retained by the authors and/or other copyright owners and it is a condition of accessing publications that users recognise and abide by the legal requirements associated with these rights.

- Users may download and print one copy of any publication from the public portal for the purpose of private study or research.

- You may not further distribute the material or use it for any profit-making activity or commercial gain

- You may freely distribute the URL identifying the publication in the public portal

If you believe that this document breaches copyright please contact us providing details, and we will remove access to the work immediately and investigate your claim 


\section{Kainic acid in the seaweed Palmaria palmata (Dulse)}

\section{Kevin Jørgensen \& Pelle Thonning Olesen}

To cite this article: Kevin Jørgensen \& Pelle Thonning Olesen (2018): Kainic acid in the seaweed Palmaria palmata (Dulse), Food Additives \& Contaminants: Part B, DOI: 10.1080/19393210.2018.1462258

To link to this article: https://doi.org/10.1080/19393210.2018.1462258

Accepted author version posted online: 15 Apr 2018.

Submit your article to this journal ๘

III Article views: 10

Q View related articles $\circlearrowright$

View Crossmark data $[\pi$ 
Publisher: Taylor \& Francis

Journal: Food Additives \& Contaminants: Part B

DOI: $10.1080 / 19393210.2018 .1462258$

\title{
Kainic acid in the seaweed Palmaria palmata (Dulse)
}

Kevin Jørgensen and Pelle Thonning Olesen

National Food Institute, Technical University of Denmark, 2800 Kgs. Lyngby, Denmark

\begin{abstract}
Twenty samples of the seaweed Palmaria palmata (dulse) purchased mainly from commercial internet shops on the European market were analysed by a liquid chromatograph coupled with a tandem mass spectrometer (LC-MS/MS) method for the content of kainic acid, a naturally occurring neurotoxic compound in $P$. palmata. Kainic acid levels in the samples ranged widely from trace levels to approximately $560 \mu \mathrm{g} \mathrm{g}^{-1} \mathrm{dry}$ weight.
\end{abstract}

Keywords: Palmaria palmata, dulse, seaweed, kainic acid

CONTACT: Kevin Jørgensen, kejo@food.dtu.dk

\section{Introduction}

Palmaria palmata (Linnaeus) F.Weber \& D.Mohr, often referred to as dulse or dillisk is a seaweed/macro alga that has been consumed historically in coastal communities of Ireland, France (Brittany), Iceland, Norway, Scotland, USA (Maine) and Canada (Nova Scotia). Today P. palmata is sold for human consumption across Europe. It may be harvested from the littoral zones in the northern Atlantic or Pacific oceans or it can be cultivated. For culinary use the seaweed can be used in a number of ways, e.g. like a salad or as a snack (Mouritsen et al. 2013).

Canadian researchers were the first to report the presence of kainic acid (Figure 1) in P. palmata (Laycock et al. 1989; Ramsey et al. 1994). The reported concentrations of kainic acid varied from below the limit of detection and up to $4000 \mu \mathrm{g} \mathrm{g}^{-1} \mathrm{dry}$ weight ( $\mathrm{dw}$ ). In two "dwarf mutant" strains the concentrations exceeded $10000 \mu \mathrm{g} \mathrm{g}^{-1} \mathrm{dw}$. They also found that the kainic acid concentration in the apical, central and basal regions of the macro algae was fairly uniform. Despite kainic acid being a well-known neurotoxin at the time, the finding went largely unnoticed. More recently six additional measurements, including samples from America and Europe, have been reported with contents ranging from 0.22 to $130 \mu \mathrm{g} \mathrm{g}^{-1} \mathrm{dw}$ (Mouritsen 2013 et al.). Though data is thus still very scarse, the data indicate that kainic acid can be found in $P$. palmata at highly variable concentrations.

Kainic acid (CAS no. 487-79-6) was originally discovered by Japanese scientists in the 1950s, as an anthelmintic constituent of the seaweed Diginea simplex (Wulfen) C. Agardh (Higa \& Kuniyoshi 2000). Kainic acid was later shown to have a potential for causing excitatory action on neurons (Shinozaki \& Konishi 1970), and its neurotoxic potential was firmly established by Olney et al. (1974). Kainic acid has subsequently become a popular model substance for studying neurophysiology (Higa \& Kuniyoshi 2000).

Presence of kainic acid in other kinds of seaweed than P. palmata has been investigated to some extend. Sato el al. (1996) investigated the content of kainic acid in 46 marine algae species. Kainic acid was detected in only 3 species: $D$. 
simplex (maximum $2760 \mu \mathrm{g} \mathrm{g}^{-1} \mathrm{dw}$ ), the seaweed where kainic acid originally was isolated from, Laurencia papillosa (maximum $10 \mu \mathrm{g} \mathrm{g}^{-1} \mathrm{dw}$ ) and Osmundaria obtusiloba (C. Agardh) R.E.Norris (Vidalia obtusiloba) (maximum $1 \mu \mathrm{g} \mathrm{g}{ }^{-1}$ dw). Impellizzeri et al. (1975) detected kainic acid in Centroceras clavulatum (C. Agardh) Montagne $\left(320 \mu \mathrm{g} \mathrm{g} \mathrm{gw}^{-1}\right.$ ), but it was not detected in 17 other marine algae. Rozas \& Freitas (2007) did not find any kainic acid in the neurotoxic seaweed Dichotomaria marginata (J.Ellis \& Solander) Lamarck (Galaxaura marginata).

Therefore the aim of this study was to acquire more information of kainic acid content originating from $P$. palmata in products sold on the European market.

\section{Materials and Methods}

\section{Sample collection}

Twenty samples of $P$. palmata products were collected. Fifteen of the samples were bought in commercial internet shops from 2013 to 2015 and analysed as they were received. Five samples were collected in 2012 to 2014 from coastal waters, four from Denmark and one from Norway. These fresh samples were freeze dried for 24 hours before analysis. Ten grams of each sample were homogenised in a blender before analysis. The content of water was determined in all samples by drying at $70^{\circ} \mathrm{C}$ under vacuum.

\section{Chemicals and reagents}

Kainic acid monohydrate was obtained from Sigma-Aldrich (St. Louis, MO, USA). A stock standard solution of kainic acid $\left(0.92 \mathrm{mg} \mathrm{mL}^{-1}\right)$ was made in acetonitrile/water $(1: 9, \mathrm{v} / \mathrm{v})$ and kept at $5^{\circ} \mathrm{C}$. Methanol and acetonitrile were of LC/MS grade from Rathburn Chemicals Ltd. (Walkerburn, Scotland). Water was purified by a Milli-Q Reference water purification system (Milford, Bedford, USA). Ammonium formate (98.7\%) was from VWR Chemicals (Leuven, Belgium) and formic acid (98-100\%) was from Merck (Darmstadt, Germany).

\section{Sample preparation}

One gram of sample was weighed in a $50 \mathrm{~mL}$ plastic centrifuge tube and extracted with $8 \mathrm{~mL} 50 \%$ methanol/water by mixing with a Ultra-Turrax (IKA, Staufen, Germany) for 1 minute. The mixture was centrifuged for 5 minutes at $2630 \mathrm{~g}$ and the extract was transferred into a $25 \mathrm{~mL}$ volumetric flask. The extraction was resumed with $8 \mathrm{~mL} 100 \% \mathrm{methanol}$ by the same procedure and a third extraction was done with $8 \mathrm{~mL} 50 \%$ methanol/water, again by the same procedure. The flask was filled to $25 \mathrm{~mL}$ with methanol. This extraction procedure was validated by extraction of the remaining sample portion of naturally positive sample pellets by the same procedure, where no more kainic acid was detected in this extra second extraction procedure. The extract was filtered (Sartorius Minisart, $0.45 \mu \mathrm{m}$, Sartorius AG, Goettingen, Germany) before injection into the LC-MS/MS.

\section{LC-MS/MS quantification}

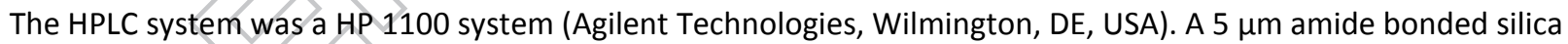
(TSK-gel Amide-80) column $(250 \times 2.0 \mathrm{~mm})$ from Tosoh Bioscience (Grove, CA, USA) was used at $20^{\circ} \mathrm{C}$. The mobile phase was $29 \%$ water and $71 \%$ acetonitrile containing $2.0 \mathrm{mM}$ ammonium formate and $3.6 \mathrm{mM}$ formic acid. The flow was $0.2 \mathrm{~mL} \mathrm{~min}^{-1}$, the injection volume was $5 \mu \mathrm{l}$ and the retention time for kainic acid was 5.9 minutes. Mass spectrometry was performed using a Micromass Quattro Ultima triple quadrupole mass spectrometer, equipped with MassLynx software for instrument control and data processing (Waters-Micromass, San Diego, California, USA). Electrospray ionization in the positive mode was used. The electrospray capillary was set at $3.5 \mathrm{kV}$ and the cone at 25 $\mathrm{V}$. The ion source block temperature was set at $130^{\circ} \mathrm{C}$, the desolvation temperature at $450^{\circ} \mathrm{C}$, and the flow rates for nitrogen bath and spray were $500 \mathrm{~L} \mathrm{~h}^{-1}$ and $90 \mathrm{~L} \mathrm{~h}^{-1}$, respectively. Data were acquired in the MRM (multiple reaction monitoring) mode. The pressure of the argon used for collision-induced dissociation was $2 \cdot 10^{-3} \mathrm{mBar}$ and the collision energy was $20 \mathrm{eV}$. The ions monitored were $\mathrm{m} / \mathrm{z} 122, \mathrm{~m} / \mathrm{z} 150$ and m/z 168, daughter ions of kainic acid: $\mathrm{m} / \mathrm{z} 214$. Similarly, for 1-hydroxykainic acid the ions monitored were $\mathrm{m} / \mathrm{z} 140, \mathrm{~m} / \mathrm{z} 168$ and m/z 186, daughter ions of $\mathrm{m} / \mathrm{z} 232$. The quantification of kainic acid was based on the most intense daughter ion $\mathrm{m} / \mathrm{z} 122$ at the chosen instrument settings. The other ions were used as confirmative ions and the ion ratio should be within $\pm 30 \%$ (relative) of average of calibration standards from same sequence. The quantification was done by five external standards of matrix 
matched kainic acid standards in the range $280-9400 \mathrm{ng} \mathrm{mL}^{-1}$. This corresponds to a quantification range from 7 to 235 $\mu \mathrm{g} \mathrm{g}^{-1}$ in seaweed. Samples with higher concentrations were diluted before quantification.

\section{Results and discussion}

\section{Method quality assurance}

Experiments at a spiking level of $92 \mu \mathrm{g} \mathrm{g}^{-1}$ gave recoveries of $92 \pm 15 \%(n=4)$. The analytical results were not corrected for recovery. The limit of quantification (LOQ) was $7 \mu \mathrm{g} \mathrm{g}^{-1}$. Three of the positive samples, in the range $120-240 \mu \mathrm{g} \mathrm{g}$, were analyzed in duplicate on two different days and the relative standard deviation ranged from 2 to $8 \%$. Based on these data a conservative estimate of the measurement of uncertainty of results is $\pm 20 \%$, with a coverage factor 2 .

\section{Analytical results}

The dry matter content of the fifteen samples bought from commercial shops was in the range of 65-91\%. The dry matter content in the five freeze dried samples was in the range of $91-95 \%$. The kainic acid concentration in the fifteen commercially sold products and five freeze dried samples is listed in table 1 . In table 2 the kainic acid concentration is corrected for the residual moisture content of the samples into $\mu \mathrm{g} \mathrm{g}^{-1} \mathrm{dw}$. This study is the most comprehensive analysis of kainic acid in P. palmata to date. The data confirm that kainic acid is a naturally occurring compound in both freshly harvested P. palmata and in the dried commercial products sold on the European market. The levels ranged from trace levels to $560 \mu \mathrm{g} \mathrm{g}^{-1} \mathrm{dw}$. Since this is still only a small study it is not unlikely that higher concentrations could be found in other P. palmata products on the European market. The results could not confirm the findings of Ramsey et al. (1994), who reported concentrations up to $4000 \mu \mathrm{g} \mathrm{g}^{-1} \mathrm{dw}$ in two $P$. palmata strains and even exceeding $10,000 \mu \mathrm{g} \mathrm{g}^{-1} \mathrm{dw}$ in two "dwarf mutant" strains. But overall, the results are in good agreement with previous findings, showing that the kainic acid concentrations in P. palmata are highly variable. Ramsey et al. (1994) also reported the presence of 1-hydroxykainic acid in $P$. palmate, whereas in this study only trace levels of this compound were found in some samples.

\section{Conclusions}

Our analysis of samples of $P$. palmata from the European market support the previous findings, that the concentration of kainic acid in P. palmata is highly variable, from trace levels to several hundred micrograms pr. gram dry weight. However, if the upper range of kainic acid content in $P$. palmata is to be properly elucidated, additional analysis needs to be conducted. A safe intake level of kainic acid remains to be established, but the data shows that it should be possible to cultivate $P$. palmata for human consumption with very low levels of kainic acid, though further research is needed to identify the factors that determine the kainic acid concentration in the seaweed.

\section{Disclosure statement}

The authors declare that there is no conflict of interest. 


\section{Funding}

This work was financially supported by The Danish Food and Veterinary Administration.

\section{References}

Higa T, Kuniyoshi M. 2000. Toxins associated with medicinal and edible seaweeds. J Toxicol-Toxin Rev. 19:119-137.

Impellizzeri G, Mangiafico S, Oriente G, Piatelli M, Sciuto S, Fattorusso E, Magno S, Santacroce C, Sica D. 1975. Amino acids and low-molecular-weight carbohydrates of some marine algae. Phytochemistry. 14:1549-1557.

Laycock MV, de Freitas ASW, Wright JLC. 1989. Glutamate agonists from marine algae. J Appl Phycol. 1:113-122.

Mouritsen OG, Dawczynski C, Duelund L, Jahreis G, Vetter W, Schröder M. 2013. On the human consumption of the red seaweed dulse (Palmaria palmata (L.) Weber \& Mohr). J Appl Phycol 25: 1777-1791.

Olney JW, Rhee V, Ho OL. 1974. Kainic acid: a powerful neurotoxic analogue of glutamate. Brain Res.77:507-512.

Ramsey UP, Bird CJ, Shacklock PF, Laycock MV, Wright JLC. 1994. Kainic acidand 1'-hydroxykainic acid from Palmariales. Nat Toxins. 2:286-292.

Rozas EE, Freitas JC. 2008. Neurotoxins in the polar fraction of the seaweed Galaxaura marginata (Rhodophyta, Nemaliales). Braz J of Phamacog. 18:160-164.

Sato M, Nakano T, Takeuchi M, Kanno N, Nagahisa E, Sato Y. 1996. Distribution of neuroexcitatory amino acids in marine algae. Phytochemistry. 42:1595-1597

Shinozaki H, Konishi S. 1970. Actions of several anthelmintics and insecticides on rat cortical neurones. Brain Res. 24:368-371. 
Table 1. Kainic acid concentration $(\mu \mathrm{gg}$-1) in commercially sold or freeze dried samples.

\begin{tabular}{|l|c|c|c|c|c|c|c|}
\hline Country & $<7^{1}$ & $7-100$ & $101-200$ & $201-300$ & $>300$ & Max. $^{2}$ & Max. $^{3}$ \\
\hline Denmark & 3 & 0 & 1 & 0 & 1 & 500 & 560 \\
\hline Norway & 0 & 0 & 0 & 1 & 0 & 230 & 240 \\
\hline Island & 3 & 1 & 0 & 0 & 0 & 13 & 15 \\
\hline Ireland & 2 & 3 & 0 & 1 & 0 & 240 & 270 \\
\hline China & 1 & 0 & 0 & 0 & 0 & $<7$ & $<7$ \\
\hline France & 0 & 1 & 0 & 0 & 1 & 430 & 470 \\
\hline Spain & 0 & 1 & 0 & 0 & 0 & 16 & 18 \\
\hline
\end{tabular}

${ }^{1}$ all samples below $7 \mu \mathrm{g} \mathrm{g}^{-1}$ (LOQ) contained trace levels of kainic acid.

2 unadjusted for moisture content.

3 adjusted to their dry weight. 
Excel Data

\begin{tabular}{|c|c|c|c|c|}
\hline sample_id* & $\begin{array}{l}\text { Analyte* }^{*} \text { kainic }\end{array}$ & value $^{*}$ & $\begin{array}{c}\text { units }^{*} \\
\mu \mathrm{g} / \mathrm{g} \text { dry }\end{array}$ & uncertainty \\
\hline 1 & $\begin{array}{l}\text { acid } \\
\text { kainic }\end{array}$ & 240 & $\begin{array}{l}\text { weight } \\
\mu \mathrm{g} / \mathrm{g} \text { dry }\end{array}$ & $\pm 20 \%$ \\
\hline 2 & $\begin{array}{l}\text { acid } \\
\text { kainic }\end{array}$ & $<7$ & $\begin{array}{l}\text { weight } \\
\mu \mathrm{g} / \mathrm{g} \text { dry }\end{array}$ & $\pm 20 \%$ \\
\hline 3 & $\begin{array}{l}\text { acid } \\
\text { kainic }\end{array}$ & $<7$ & $\begin{array}{l}\text { weight } \\
\mu \mathrm{g} / \mathrm{g} \text { dry }\end{array}$ & $\pm 20 \%$ \\
\hline 4 & $\begin{array}{l}\text { acid } \\
\text { kainic }\end{array}$ & 130 & $\begin{array}{l}\text { weight } \\
\mu \mathrm{g} / \mathrm{g} \text { dry }\end{array}$ & $\pm 20 \%$ \\
\hline 5 & $\begin{array}{l}\text { acid } \\
\text { kainic }\end{array}$ & 15 & $\begin{array}{l}\text { weight } \\
\mu \mathrm{g} / \mathrm{g} \text { dry }\end{array}$ & $\pm 20 \%$ \\
\hline 6 & $\begin{array}{l}\text { acid } \\
\text { kainic }\end{array}$ & $<7$ & $\begin{array}{l}\text { weight } \\
\mu \mathrm{g} / \mathrm{g} \text { dry }\end{array}$ & $\pm 20 \%$ \\
\hline 7 & $\begin{array}{l}\text { acid } \\
\text { kainic }\end{array}$ & 270 & $\begin{array}{l}\text { weight } \\
\mu \mathrm{g} / \mathrm{g} \text { dry }\end{array}$ & $\pm 20 \%$ \\
\hline 8 & $\begin{array}{l}\text { acid } \\
\text { kainic }\end{array}$ & 63 & $\begin{array}{l}\text { weight } \\
\mu \mathrm{g} / \mathrm{g} \text { dry }\end{array}$ & $\pm 20 \%$ \\
\hline 9 & $\begin{array}{l}\text { acid } \\
\text { kainic }\end{array}$ & 91 & $\begin{array}{l}\text { weight } \\
\mu \mathrm{g} / \mathrm{g} \text { dry }\end{array}$ & $\pm 20 \%$ \\
\hline 10 & $\begin{array}{l}\text { acid } \\
\text { kainic }\end{array}$ & $<7$ & $\begin{array}{l}\text { weight } \\
\mu \mathrm{g} / \mathrm{g} \text { dry }\end{array}$ & $\pm 20 \%$ \\
\hline 11 & $\begin{array}{l}\text { acid } \\
\text { kainic }\end{array}$ & $<7$ & $\begin{array}{l}\text { weight } \\
\mu \mathrm{g} / \mathrm{g} \text { dry }\end{array}$ & \\
\hline 12 & $\begin{array}{l}\text { acid } \\
\text { kainic }\end{array}$ & $<7$ & $\begin{array}{l}\text { weight } \\
\mu \mathrm{g} / \mathrm{g} \text { dry }\end{array}$ & \\
\hline 13 & $\begin{array}{l}\text { acid } \\
\text { kainic }\end{array}$ & 60 & $\begin{array}{l}\text { weight } \\
\mu \mathrm{g} / \mathrm{g} \text { dry }\end{array}$ & \\
\hline 14 & $\begin{array}{l}\text { acid } \\
\text { kainic }\end{array}$ & $<7$ & $\begin{array}{l}\text { weight } \\
\mu \mathrm{g} / \mathrm{g} \text { dry }\end{array}$ & $\pm 20 \%$ \\
\hline 15 & $\begin{array}{l}\text { acid } \\
\text { kainic }\end{array}$ & 7 & & $\pm 20 \%$ \\
\hline 16 & $\begin{array}{l}\text { acid } \\
\text { kainic }\end{array}$ & & & $\pm 20 \%$ \\
\hline 17 & $\begin{array}{l}\text { acid } \\
\text { kainic }\end{array}$ & & $\begin{array}{l}\text { weight } \\
\mu \mathrm{g} / \mathrm{g} \text { dry }\end{array}$ & \\
\hline 18 & & & $\begin{array}{l}\text { weight } \\
\mu \mathrm{g} / \mathrm{g} \text { dry }\end{array}$ & $\pm 20 \%$ \\
\hline 19 & & 8 & $\begin{array}{l}\text { weight } \\
\mu \mathrm{g} / \mathrm{g} \text { dry }\end{array}$ & $\pm 20 \%$ \\
\hline 20 & acid & 31 & weight & $\pm 20 \%$ \\
\hline
\end{tabular}




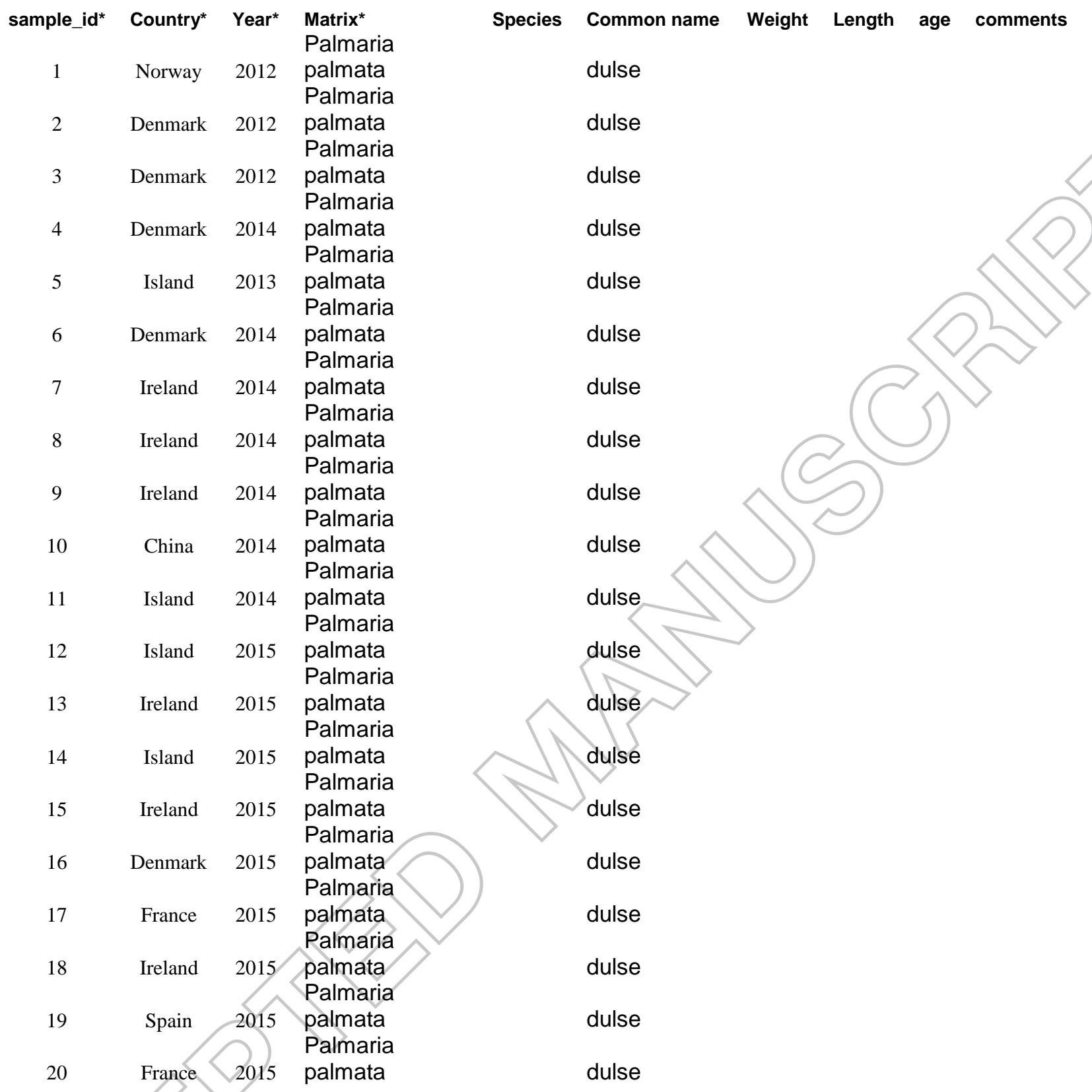


Figure 1. Chemical structure of kainic acid.

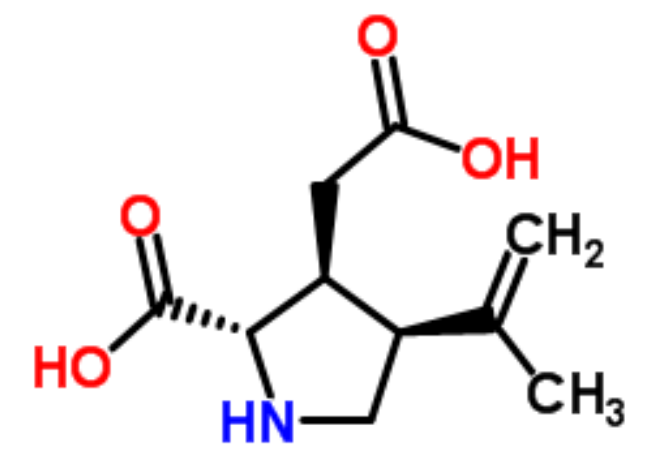

